\title{
European Online Master Degree Program for Addressing Labor Market Demands
}

\author{
http://dx.doi.org/10.3991/ijoe.v8iS3.2243
}

\author{
Mohamed Tawfik ${ }^{1}$, Elio Sancristobal ${ }^{1}$, Sergio Martin ${ }^{1}$, Rosario Gil $^{1}$, Alberto Pesquera ${ }^{1}$, Maria Jose Albert ${ }^{1}$, \\ Gabriel Diaz ${ }^{1}$, Juan Peire ${ }^{1}$, Mihail Milev ${ }^{2}$, Nevena Mileva ${ }^{3}$, Gearoid OSuilleabhain ${ }^{3}$, Slavka Tzanova ${ }^{4}$, Chris- \\ tian Kreiner ${ }^{5}$, Leander Bernd Hörmann ${ }^{5}$, Manuel Castro ${ }^{1}$ \\ ${ }^{1}$ Spanish University for Distance Education (UNED), Spain \\ ${ }^{2}$ Plovdiv University (PU), Plovdiv, Bulgaria \\ ${ }^{3}$ Cork Institute of Technology (DEIS), Cork, Ireland \\ ${ }^{4}$ Technical University Sofia (TUS), Sofia, Bulgaria \\ ${ }^{5}$ Graz University of Technology (TUGraz), Graz, Austria
}

\begin{abstract}
Demands and needs of labor markets have always been seldom concerned by providers of educational programs. Most of the educational curricula revolve around the theoretical concepts and their evolution without contemplating their purpose of deployments and application. This is common in most of the engineering curricula and the applied science. In this contribution, we present a new European project, Remote-labs Access in Internet-based Performance-Centered Learning Environment for Curriculum Support (RIPLECS) that aims to mitigate these issues by providing an official inter-institutional European master degree program in Information and Communication System (ICS). In order to globalize the master and to, at least, guarantee its accordance with the European education requirements, the program is conducted online across five European institutions and is oriented to labor market needs for qualified graduates, with special focus on realizing realworld experiments in each subject remotely, which tackle many geographical and time constrains. The network architecture of RIPLECS platform enables world-wide distribution of learning resources by utilizing multiple Web servers at several European universities, within a single network topology. The paper discusses the project development stages, implementation and the expected outcomes.
\end{abstract}

Index Terms-remote laboratories, distance education, Elearning, online learning

\section{INTRODUCTION}

Among the remarkable reasons that are struggling the European sustainable growth objectives and are working the unemployment situation in Europe are the deficits in qualified and skilled graduates and professionals. The following recommendations from the report "Investing in the Future of Jobs and Skills" [1] specifically address education and training needs in the computer, optical and electronics industrial sectors: Enhance the flexibility in education and training by promoting modularization; facilitation of Life-Long Learning; know-how transfer learning and establish learning networks; Enhance flexibility in e-learning and blended learning; Supply special courses dedicated to a sector characteristics.

This paper presents one of the few approaches that concerns the labor market needs. The paper reports on an online official inter-institutional master degree program in
Information and Communication Systems (ICS), which is conducted by Five European institutions and is oriented to labor market needs for qualified professionals, with special focus on accessing laboratory experiments remotely and thus, learning flexibility and efficiency are granted. The program is created within the new European project, Remote-labs Access in Internet-based Performancecentered Learning Environment for Curriculum Support (RIPLECS) [2]. The network architecture of RIPLECS platform enables the world-wide distribution of learning resources and lab-experiments, by utilizing multiple Web servers at several universities in Europe, within a single network topology. Thus, instructors from different European countries can take the advantages of conducting the program and deploying remote lab experiments in their native language and personal educational point of view. Obviously, each supervisor will have the opportunity to review his users' performance by his own criteria, according to the assessments rules for each experiment.

The project partners have already been working for the last five years on applying performance-centered methodology in university education, training and vocational education starting with IPSS_EE Minerva project [3], and then continuing with DIPSEIL [4] and IPLECS projects [5]. The DIPSEIL project provides an integrated master program in a platform for open and easily accessible learning resources, which answer to the global strategy for the effective integration of information and communications technology (ICT) in higher education, realizing the effective virtual mobility of students and staff. A distributed performance-centered adaptive Learning Management System (LMS), for IT, telecommunication, microelectronic and electronic courses, was set-up, and five DIPSEIL servers in four countries in Europe has been installed, as shown in Figure 1. In addition, a pool of learning resources on DIPSEIL database in four different languages is provided.

The IPLECS project was an extension to the DIPSEIL project and it has proved that developed performancecentered reusable and open course learning materials could be used to support university curriculum in the field of engineering education. Under the IPLECS project, almost 50 performance-centered courses in five languages has been add to the DIPSEL platform and a whole Master degree program has been implemented at one university 


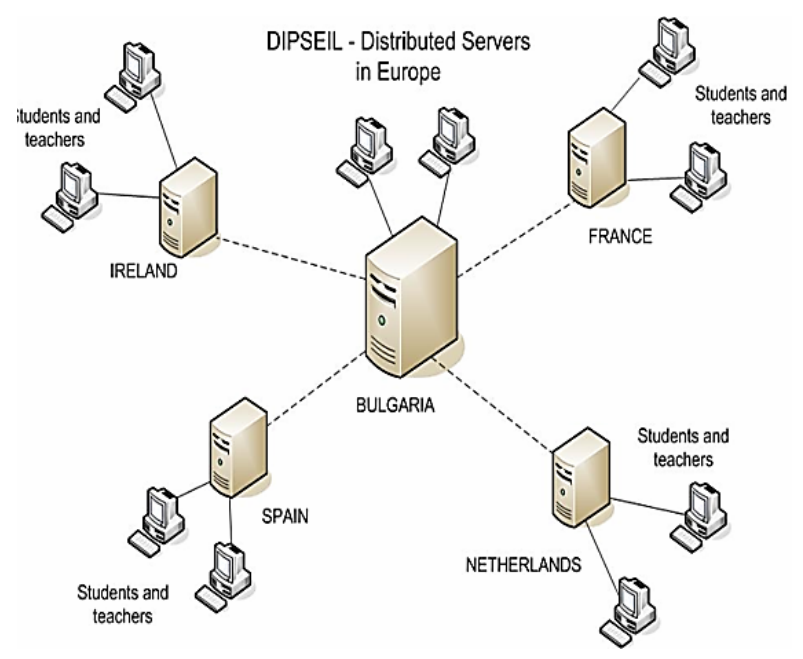

Figure 1. Five DIPSEIL servers in four European countries.

and some courses from the program has been implemented at the other four universities.

The aforementioned carried out projects and the acquired experiences by the partners returned strong positive results; these learning tools have been proven to be more effective than their traditional counterparts in training and preparing learners, and adapting them for the labor market needs. However, the feedback from the employers of graduated students and from a number of enterprises in the sector during the implementation of courses was that more practical skills are expected and more laboratory practices are necessary. The preliminary analysis has also shown that whilst there already exists considerable ICT multimedia content on web servers, there does not yet exist a telematics based educational and training service for ICT in Europe. In response to these needs, the partners have launched the RIPLECS project to create such a telematicsbased educational and training service for ICT in Europe by developing remote accessed laboratories in multiple disciplines. The goal in a concrete manner is a realization of practical tasks performance in courses from the complete master degree program through remote access to laboratories. In general, the project will work towards providing Open Educational Resources (OER) for virtual campuses by ensuring that organizational, technical and quality-related issues are addressed in order to share content, and make it easily accessible at European level and developments of the European Higher Education Area (EHEA) objectives for 2020, according to the Bologna process [6].

The rest of the paper is structured as follows: Section II provide a background on remote laboratories, their advantages and the necessity of their integration in the engineering curricula. Section III provides an overview on the RIPLRCS project, the new master degree program and the estimated outcomes of the project. Section IV provides a brief description on various developed remote laboratories to be integrated in the master degree program. Finally, a conclusion is drawn in Section V.

\section{REMOTE LABORATORIES}

The accelerated pace at which both the computing and telecommunications technologies are advancing, along with their ever increasing availability, are creating a new relationship between the teaching process and the way students are learning, thus revolutionizing the way this process is carried out altogether. Web-based course management and delivery software, such LMSs [7, 8], are becoming common in many areas of education. However, the facilities provided by such systems do not consider practical laboratory work. Given that experimental work is a vital component of science and engineering teaching at all levels. On the other hand, the style of life of today's students requires more flexibility in terms of accessing information without neither geographical nor time constrains. All these consideration have raised a big interest among universities in the last decade in moving towards delivering remote access to their lab facilities, ensuring a richer collaborative experience for the student while avoiding some of the growing limitations of traditional laboratories, such as the lack of enough work area, expensive instrumentation, lack of personnel, time assigned to a laboratory, and their availability in non-working office hours. Several successful initiatives/projects have been carried out, either creating singular remote lab solutions [9-12] (e.g. VISIR [13, 14], NetLab [15], DIESEL [16] and PEARL [17]) or community based approaches for delivering remote access to a pool of sharable laboratories among partners within a community [18] (e.g. iLab [19], Labshare [20], and Weblab Deusto [21]), or integrating remote laboratories within LMSs to take the advantages of the services provides by LMSs such as communication tools, administration, and assessments (e.g. the middleware architecture described in [22-25], and LiLa [26]), or indexing remote laboratories within a metadata repository in order to facilitate for researchers to allocation of information about remote labs dispersed among many universities (e.g. Lab2go [27] and iLab Central [28]).

So far, little efforts have been made in order to integrate remote access to laboratories into official engineering courses and thus, few results have been collected; most of the implementations within remote labs projects are usually conducted as an optional solution along with hands-on traditional laboratories. Considering the need of preparing qualified engineering curricula oriented to the labor market and the required flexibility of accessing educational resources, the RIPLECS project has launched to be an extension for the IPLECS project but considering the well integration of remote laboratories in an official European master program developed within the project and conducted among the partners' institutions . Next, a brief description of the project is presented.

\section{PROJECT DESCRIPTION}

The RIPLECS project provide an effective integration of ICT and OER in the participating higher education institutions by enabling open educational resources for virtual campuses, in order to share learning objects and make it easily accessible at European level, and strengthening virtual mobility by integrating access to remote laboratories and the realization of practical tasks performance in courses from the complete European master degree program in ICS. The project partners are:

- Electrical \& Computer Engineering Department, Spanish University for Distance Education (DIEECUNED), Spain. 
- Communication \& Control Systems Department, Spanish University for Distance Education (DSCCUNED), Spain.

- University of Plovdiv (PU), Bulgaria.

- Cork Institute of Technology (DEIS), Ireland.

- Technical University of Sofia (TUS), Bulgaria.

- Institute for Technical Informatics, Graz University of Technology (TUGraz), Austria.

The master program is targeted to engineers, technicians and scientists with interest on up-to date topics in the area. This master-degree title gives a deeper and complete formation in the ICS research areas, as well as development activities linked to professional sectors. Recent advances in electronics components and systems, advanced design, advanced communication electronic systems or application techniques in industrial sectors will be shown. Students will acquire skills focused on industrial field like production organization, design of products, processes and installations, quality management or multidisciplinary teams' management. Additionally, different training and educational activities focused on research processes related to the electronics engineering field will be carried out.

The program will start in the academic year 2013/2014 and will be delivered as many years as the labor market needs ICT specialists and students want to enroll for the master degree curriculum. Enterprises in the sector of ICT need design and production engineers and scientists skilled in more than just one area of research which should be able to work with the newest technological equipment. Thus, part of the project management will include contacting and collaboration with enterprises in the sector to respond to the labor market needs.

The curriculum courses are based on ECTS and it will be conducted and accredited initially in Spain, by the Spanish ANECA accreditation Agency [29], as part of the official courses conducted at Spanish University for Distance Education (UNED). This is owing to the vast historical experience of UNED in delivering online educational programs - UNED is the second distance education university in the Europe in terms of number of "online" enrolled students [30] after the Open University in United Kingdom, the actual number of enrolled students is 260.079. In addition, a certification from all partner universities will be included. The consortium unites universities teaching engineering and science, and open universities. It encompasses members from four European countries with four different languages and from different application domains, including mathematics, physics, microelectronics, information technology and telecommunications.

The master program is of one year ( 2 semesters) and 60 ECT, and is composed of three modules; fundamental module, specialized module, and final project module. The subjects are of 5 ECT, and the final project is of 10 ECT. All subjects will be taught in English and any student around the world could be registered and enrolled in the master. Moreover, remote laboratories will form an integral part within the subjects of the master program. The program curriculum is organized as shown in Table 1.

RIPLECS relies on the DIPSEIL platform which enables the world-wide distribution of learning resources and remote lab experiments. A DIPSEIL server will be installed at each partner's institution within a single network topology. Thus, instructors at each institution could take the advantages of employing learning resources and lab experiments and present it in their native language and personal educational point of view. It is obvious that multiple simultaneous accesses to the instrument server would not make sense because different settings from different students to one instrument could not be handled. Therefore it is necessary to do experiments sequent. Since access is carried out remotely, a scheduling system must be implemented, consisting of an access web page in which the user, having previously requested a user account and being validated by the lab administrator, logs in and selects up to one or two hours to access the automation station.

The concept of Internet accessible labs encourages rossinstitution cooperation. Students at one university will access remotely to a laboratory made accessible by a second university. Partnership organizations will share the cost of an expensive laboratory and physically establish it at a convenient location. Students will have a possibility to have practical work in labs in different countries, which labs are usually very expensive (in some cases they are unavailable for public universities), and that offer practical experiments or technology with high quality, or limited access.

The effect of practical tasks performance and performance-centered learning resources on knowledge, skills and attitudes of different types of learners will be evaluated as applying some classical methods such as observation, surveys through questionnaires and interviews, and analysis of information flow from the discussion forum through grounded theory techniques and content analysis. In addition, the project will use some more advanced research methods such as cognitive mapping. The observation protocols, questionnaires and the interviews' forms will be tested for validity and reliability. A combination of

TABLE I.

Curriculum of the RIPLECS Master Program

\begin{tabular}{|c|c|c|}
\hline & Subject & \multirow{2}{*}{$\begin{array}{l}\text { Provider } \\
\text { PU }\end{array}$} \\
\hline \multirow{13}{*}{ 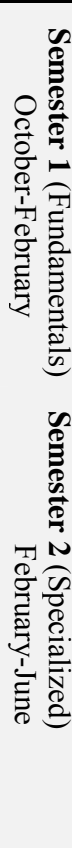 } & \multirow{4}{*}{$\begin{array}{l}\text { - Introduction to Information and } \\
\text { Telecommunication systems } \\
\text { - Industrial and Real-time } \\
\text { Communications } \\
\text { - Internet Technology } \\
\text { - Electronics for Information and } \\
\text { Communication Technologies } \\
\text { - ICTs research and enoineering }\end{array}$} & \\
\hline & & DIEEC-UNED \\
\hline & & DEIS \\
\hline & & TUS \\
\hline & $\begin{array}{l}\text { - ICTs research and engineering } \\
\text { competence skills }\end{array}$ & DSCC-UNED \\
\hline & - Microprocessor Techniques & PU \& DIEEC-UNED \\
\hline & - Wireless Communications & PU \& TUGraz \\
\hline & - Multi Media & DEIS \\
\hline & $\xi_{0}^{-} \quad$ - Power Supplies for ICT & DIEEC-UNED \\
\hline & $\frac{2}{2}-$ Microelectronics & PU \\
\hline & $\begin{array}{l}\text { ह. Satellite and Mobile } \\
\text { के Communications }\end{array}$ & PU \& DIEEC-UNED \\
\hline & $\begin{array}{l}\text { - Computer Modeling and } \\
\text { Simulation of Electronic } \\
\text { Circuits }\end{array}$ & PU \& DIEEC-UNED \\
\hline & \multicolumn{2}{|c|}{ Final Project } \\
\hline
\end{tabular}


inductive coding of grounded theory techniques and deductive coding of content analysis will help for an accurate identifying of the main categories and themes. It will lead to building of conceptual models.

In the next section, a brief description is presented on the developed remote laboratories that are going to be integrated within the subjects of the master program. However, more remote laboratories are currently under development and are due to be running the beginning of the academic year 2013/2014.

\section{ROLE OF REMOTE LABORATORIES}

\section{A. Virtual Instrument Systems in Reality (VISIR)}

VISIR is a remote laboratory for measuring and wiring electronic circuits on a virtual breadboard that mimics the real physical one. The wiring mechanism is developed by means of a relay switching matrix connected to a PXI (PCI eXtensions for Instrumentation) instrumentation platform, Figure 2. The entire equipment is controlled by a LabVIEW server software, in addition to measurement server software that protects the equipment by verifying input circuit designs, sent by students, before being executed. The user designs and constructs his circuit by a PCmouse on a seamlessly simulated workbench that resembles the real lab elements and components. Once the designed circuit is submitted, it is sent to be verified then to be wired and measured by real instruments, and finally, to be received by the user on his PC-screen in real-time. Further information about the system is found in $[13,14$, 31-33]. VISIR is currently installed in the DIEEC-UNED and was successfully being deployed in electronic practices of several subjects in the department, for more two years. VISIR is planned to be integrated in the practices of the subjects: Industrial and Real-time Communications, and Power Supplies for ICT equipment. The proposed practices include:

- Basic electronic circuits.

- Filter circuits

- Amplifier circuits.

- Transistor circuits: BJT, MOSFET, and IGPT.

- Converters: DC/AC, AC/AC, DC/DC, AC/DC.

- Power supply circuits.

\section{B. Embedded Systems Remote Labs}

Embedded systems remote labs are a collection of mounted boards such as Field-programmable Gate Array (FPGA), Microprocessor, and microcontroller, which are totally administrated, controlled, and monitored online for education and experimentation boards (Figure 3). The current board versions are Xilinx 3AN Spartan, Motorola 68000, and PIC16F88X. The students use these types of boards in order to program them online by programming languages such as VHSIC hardware description language (VHDL) and to monitor the results through a connected Webcam. Embedded systems remote labs are already in operation at DIEEC-UNED and are expected to be deployed in the subject Microprocessor Techniques.

\section{Remote Lab for Wireless Sensor Networks (WSNs)}

Wireless Sensor Networks (WSNs) connect small electronic devices with each other and represents computer architectures in the small world. These networks consist of highly integrated wireless sensor nodes, which are able to

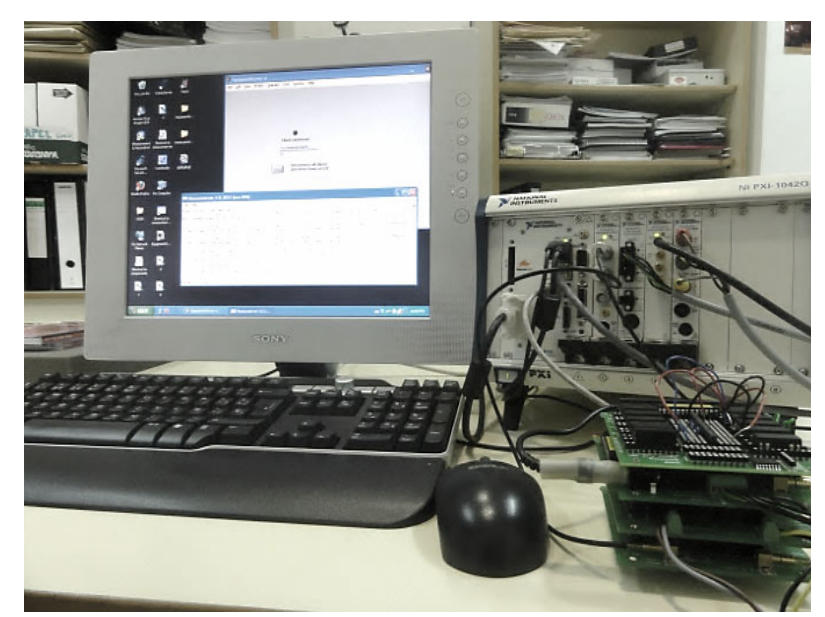

Figure 2. VISIR at DIEEC-UNED.

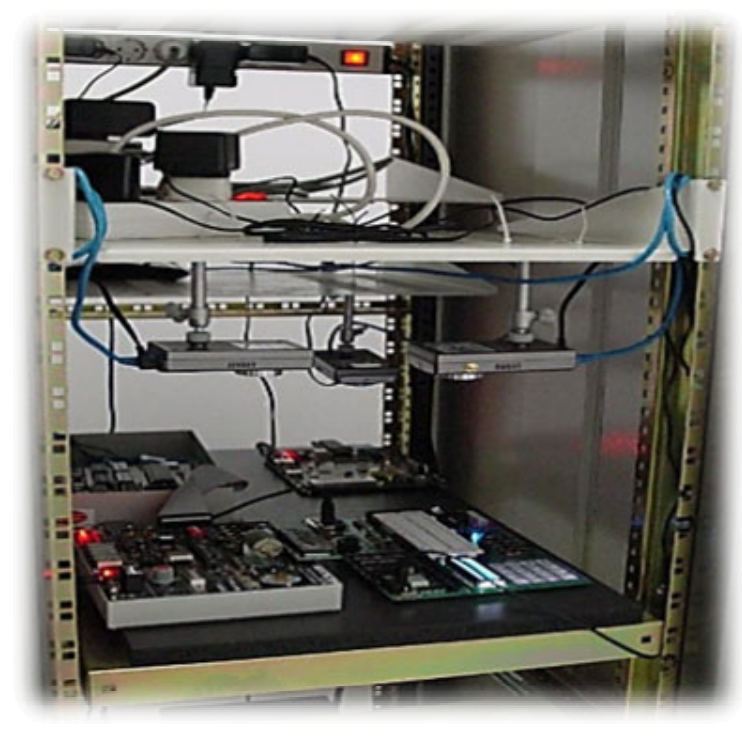

Figure 3. Embedded systems remote labs.

measure specific values of the environment, to process the measured data and to communicate with other wireless sensor nodes. WSNs are used in application areas with mobility or no wired infrastructure. Examples are: precision agriculture [34], wildlife monitoring [35], human health care [36], and structural health monitoring [37]. Further fields of application are for example vehicle detection and various commercial applications. The subject Wireless Communications provided by PU and TUGraz gives an overview on the state-of-the-art communication systems and how a WSN works. The practical part consists of several assignments dealing with configuration and programming a WSN through a remote laboratory provided by TUGraz. The lab system is shown in Figure 4 and it consists of six main components:

- Remote Access and Experiment Control Server: It is directly connected to the equipment and hosts the user interface application and the control software of the experiment.

- Base Station: It exchange data and status messages, control and program update messages between the WSN and the remote access and experiment control server. 


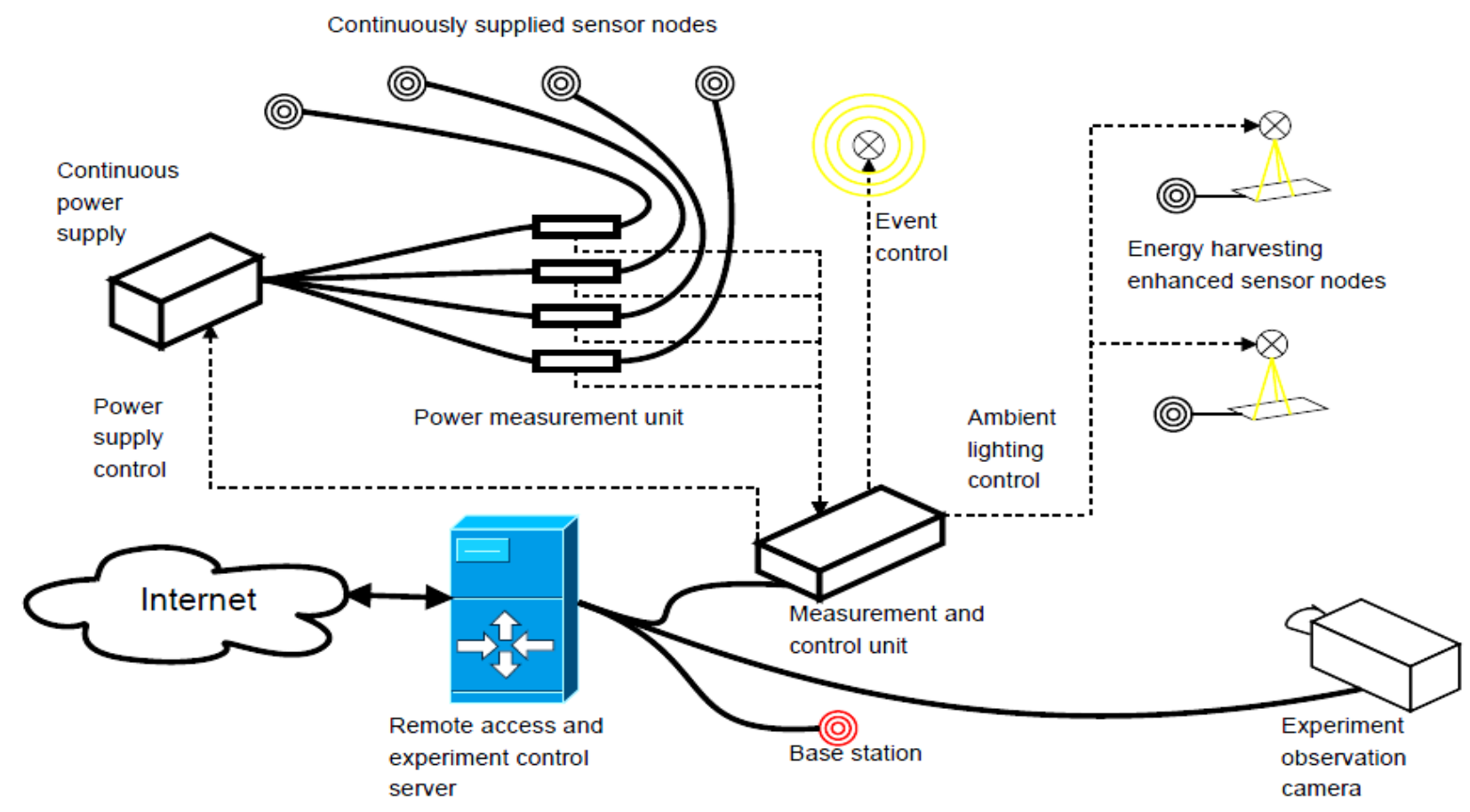

Figure 4. Remote lab for WSN.

- Continuously Supplied Sensor Nodes: They are programmed and configured in order to teach the basic function of a WSN. They are supplied by switchable continuous power supply, and thus, can be switched $\mathrm{OFF} / \mathrm{ON}$ remotely. This is needed to test the fault tolerance of the WSN and the running software on it (especially routing protocols).

- Energy Harvesting Enhanced Sensor Nodes: They are programmable nodes that are equipped with solar cells and connected wirelessly to the network.

- Measurement and Control Unit: The measurement and control unit enables: measurement of the power consumption of the continuously supplied sensor nodes; ambient lighting by simulating lighting condition during a whole day including sunrise, day light, sunset, and night; switching power supply connections; and driving the event source, which is used to generate events that should be detected by the sensor nodes (in the application scenario it simulates the flashlight of a housebreak which must be detected by the wireless alarm system).

- Experiment Observation Camera: It is used to view the remote lab setup in real time.

\section{Remote Lab for GSM and $3 G$ Telecommunications}

Antennas are essential components in wireless communications that allows transmitting and receiving waves. They are widely used in many applications such as radio broadcasting, communications receivers, radars, cell phones, and satellites. Parameters used to test the performance of an antenna are radiation pattern, directivity, gain, polarization, impedance and bandwidth. Radiation pattern and gain are considered as basic parameters of an antenna and therefore, they are commonly studied in student's tutorials. In the same subject Wireless Communications, an overview is given on the characteristics of different types of antennas used in wireless communica- tions and the wave propagation in mobile communication. The practical part of both tasks is carried out by a remote lab provided by PU, seen in Figure 5. Different types of antennas cab be replaced remotely by an External Antenna Switching Controller Board (EASCB) and real wave environment is emulated by a built-in hardware circuit. The goals are: measuring the radiation patterns of various types of antennas to get a clear picture on their radiation characteristics, and measuring characteristics of wave propagation in mobile communications identifying fading, phase delay, standing wave, Doppler frequency, etc.

\section{E. Cadence Virtuoso Platform}

Cadence is considered to be the industry standard Electronic Design Automation (EDA) tool for Complementary metal-oxide-semiconductor (CMOS) integrated circuits (ICs) layout and solving problems with modeling of submicron devices behavior. However the cadence license is expensive for students, thus TUS will implement remote accessed workstations of cadence Virtuoso platform

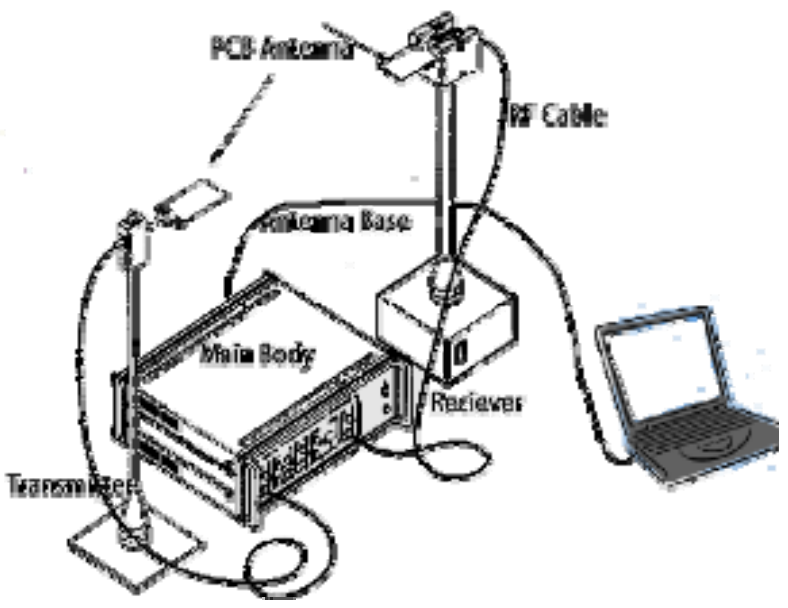

Figure 5. Remote lab for GSM and 3G telecommunications. 


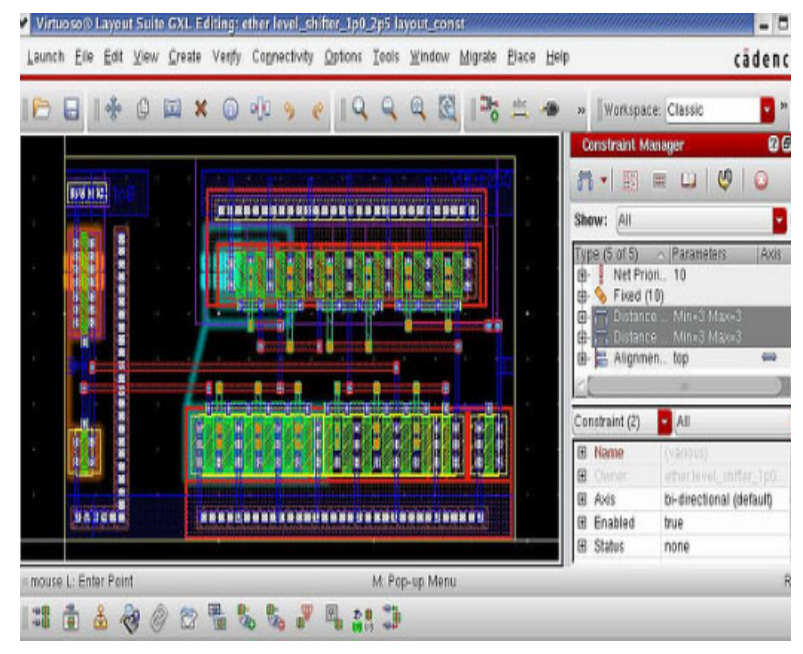

Figure 6. Cadence Virtuoso Platform.

(Figure 6) for the subject Electronics for Information and Communication Technologies in order to provide students with specialized knowledge on CMOS integrated circuit layout, basic technology, IC design and modeling. Having the remote lab definition and concept in mind, this type of experimentation might not be listed as a remote laboratory as it doesn't deal with real instruments. It is considered a virtual laboratory that is enabled through remote access to virtual machines at the hosting university.

The mentioned laboratories have already been developed and ready for their integration in the master degree program. Further remote labs are currently under development including mobiles and embedded systems [38], which are expected to be ready due the commencement of the master.

\section{CONCLUSION}

Despite the shortness in skilled and qualified graduates and the requirement of the labor market needs. So far, few initiatives have been done in these regards. The RIPLECS aims to address these demands imposed by the labor markets through a European master degree program that provides a ubiquitous pool of learning resources and lab experiments from multiple European institutions. The variety of partners form diferent European institutions would enrich and augment the program contents and will deliver experiences and outcomes that are in accordance with the European education requirements. The program is conducted by European partners, however, being online, it would include students from all over the world and it will be compatible with different life styles of the predominating students. Putting all these factors together makes the program unique of its kind. Thus, its successful implementation would pave the way for further initiatives of this kind, which are not only confined neither to ICS nor Engineering either, but for many other disciplines of science.

\section{ACKNOWLEDGMENT}

Authors would like to acknowledge the following projects: RIPLECS (517836-LLP-1-2011-1-ES-ERASMUSESMO), e-Madrid (S2009/TIC-1650), PAC (517742-LLP1-2011-1-BG-ERASMUS-ECUE), EMTM (2011-1-PL1LEO05-19883), and the NSF Catalyzing New Interna- tional Collaborations proposal "Building an Ecology of Online Laboratories".

As well, authors would like to acknowledge the support of the Spanish Ministry for Economy and Competitiveness for the granted internship for Mr. Tawfik at University of Technology, Sydney (UTS) within the project s-Labs (TIN2008-06083-C03-01).

\section{REFERENCES}

[1] "Investing in the Future of Jobs and Skills. Scenarios, implications and options in anticipation of future skills and knowledge needs for the Computer, Electronic and Optical Products Sector," Policy SummaryMay 2009.

[2] (2012). RIPLECS Project - Remote-labs access in Internet-based Performance-centred Learning Environment for Curriculum Support. Available: http://riplecs.dipseil.net/

[3] S. Tzanova, N. Mileva, M. A. C. Gil, J. van Merrienboer, C. M. Mediano, C. Schaeffer, J. Nikolics, and K. Stefanova, "Internetbased Performance Support Systems with Educational Elements (IPSS-EE) for engineering education," in Frontiers in Education, 2002. FIE 2002. 32nd Annual, 2002, pp. S3E-8-S3E-9 vol.3.

[4] E. Lopez, E. Sancristobal, S. Martin, G. Diaz, M. Castro, J. Peire, J. M. Gomez, and P. Lopez, "Internet-based teaching evolution in Computer Architecture," in Frontiers in Education Conference, 2008. FIE 2008. 38th Annual, 2008, pp. T2B-15-T2B-20.

[5] C. Martinez-Mediano, M. Castro, N. Rioperez, G. N. Mileva, S. Stoyanov, S. Tzanova, W. Kicken, Diaz, E. Sancristobal, S. Varela, and S. Martin, "Internet-based performance-centered learning environment for Curriculum Support (IPLECS) and its application in mLearning," in Education Engineering (EDUCON), 2010 IEEE, 2010, pp. 819-824.

[6] (2012). The Bologna Process 2020 - The European Higher Education Area in the new decade. Available: http://www.ond.vlaanderen.be/hogeronderwijs/bologna/co nference/documents/Leuven Louvain-laNeuve Communiqu \%C3\% $\%$ April 2009.pdf

[7] E. Sancristobal, A. Pesquera, M. Tawfik, M. Latorre, F. GarciaLoro, R. G. E. Ruiz, S. Martín, G. Diaz, A. Colmenar, and M. Castro, "Learning Management Systems and Online Labs within Virtual Worlds," in Remote Eng. \& Virtual Instrum. (REV) 2011, Brasov, Romania, 2011, pp. 78-82.

[8] M. Castro, M. Llamas, G. Diaz, E. Sancristobal, S. Martin, R. Gil, M. Tawfik, M. Caeiro, J. Fontenla, R. Pastor, R. Hernandez, S. Ros, A. Pesquera, J. Garcia-Zubia, P. orduna, J. M. Gomez, E. Tovar, Ó. Martinez-Bonastre, and L. Vicent, "Servicios para Plataformas Educativas: Laboratorios y Aplicaciones," in TAEE 2010. IX Congreso de Tecnologías Aplicadas a la Enseñanza de la Electrónica, Madrid, Spain, 2009.

[9] M. Tawfik, E. Sancristobal, S. Martin, R. Gil, G. Diaz, J. Peire, and M. Castro, "On the Design of Remote Laboratories," in Global Engineering Education Conference (EDUCON), IEEE, Marrakesh, 2012, pp. 1-6.

[10] M. Tawfik, E. S. Cristobal, A. Pesquera, R. Gil, S. Martin, G. Diaz, J. Peire, M. Castro, P. Orduna, and J. Garcia-Zubia, "Putting fundamentals of electronic circuits practices online," in Technologies Applied to Electronics Teaching (TAEE), 2012, 2012, pp. 117-121.

[11] M. Tawfik, E. Sancristobal, S. Martin, G. Diaz, and M. Castro, "State-of-the-art remote laboratories for industrial electronics applications," in Technologies Applied to Electronics Teaching (TAEE), 2012, 2012, pp. 359-364.

[12] R. Pastor, D. Sanchez, N. Aliane, R. Hernandez, G. Mariscal, A. Robles-Gomez, A. Caminero, S. Ros, M. Tawfik, E. S. Cristobal, G. Diaz, and M. Castro, "Structured remote laboratory development," in Technologies Applied to Electronics Teaching (TAEE), 2012, 2012, pp. 314-319. http://dx.doi.org/ 10.1109/TAEE.2012.6235457

[13] M. Tawfik, E. Sancristobal, S. Martín, C. Gil, P. Losada, G. Díaz, and M. Castro, "Design of Practical Activities in Electronics Using Visir Remote Laboratories," in VII International Conference on Engineering and Computer Education (ICECE 2011), UMINHO - University of Minho, Guimarães, 2011. 
[14] M. Tawfik, E. Sancristobal, S. Martín, C. Gil, A. Pesquera, P. Losada, G. Díaz, J. Peire, and M. Castro, "A New Node in the VISIR Community," in Remote Eng. \& Virtual Instrum. (REV) 2011, Brasov, Romania, 2011, pp. 16-22.

[15] (2012). NetLab Available: http://netlab.unisa.edu.au/ index.xhtml

[16] M. J. Callaghan, J. Harkin, T. M. McGinnity, and L. P. Maguire, "Intelligent User Support in Autonomous Remote Experimentation Environments," IEEE Trans. Ind. Electron., vol. 55, pp. 23552367, 2008. http://dx.doi.org/10.1109/TIE.2008.922411

[17] M. Cooper and J. M. M. Ferreira, "Remote Laboratories Extending Access to Science and Engineering Curricular," Learning Technol., IEEE Trans. on, vol. 2, pp. 342-353, 2009.

[18] M. Tawfik, E. S. Cristobal, A. Pesquera, R. Gil, S. Martin, G. Diaz, J. Peire, M. Castro, R. Pastor, S. Ros, and R. Hernandez, "Shareable educational architectures for remote laboratories," in Technologies Applied to Electronics Teaching (TAEE), 2012, 2012, pp. 122-127.

[19] V. J. Harward, J. A. del Alamo, S. R. Lerman, P. H. Bailey, J. Carpenter, K. DeLong, C. Felknor, J. Hardison, B. Harrison, I. Jabbour, P. D. Long, M. Tingting, L. Naamani, J. Northridge, M. Schulz, D. Talavera, C. Varadharajan, W. Shaomin, K. Yehia, R. Zbib, and D. Zych, "The iLab Shared Architecture: A Web Services Infrastructure to Build Communities of Internet Accessible Laboratories," Proceedings of the IEEE, vol. 96, pp. 931-950, 2008. http://dx.doi.org/10.1109/JPROC.2008.921607

[20] (2012). Labshare - Home. Available: http://www.lab share.edu.au/

[21] (2012). WebLab Deusto. Available: https://www.weblab. deusto.es

[22] M. Tawfik, E. Sancristóbal, S. Martín, C. Gil, A. Pesquera, S. Ros, R. Pastor, R. Hernández, G. Díaz, J. Peire, and M. Castro, "Towards a Better Deployment of Remote Laboratories in Undergraduate Engineering Education," in Using Remote Labs in Education: Two Little Ducks in Remote Experimentation, J. G. Zubía and G. R. Alves, Eds., ed Bilbao: University of Deusto, 2011.

[23] E. Sancristobal, M. Castro, J. Harward, P. Baley, K. DeLong, and J. Hardison, "Integration view of Web Labs and Learning Management Systems," in IEEE Global Eng. Educ. Con. (EDUCON) 2010, pp. 1409-1417.

[24] R. Gil, E. S. Cristóbal, M. Tawfik, S. Martín, A. Pesquera, G. Díaz, A. Colmenar, J. Carpio, J. Peire, and M. Castro, "Applications and Security in the Practical Competitiveness Implementation within Learning Environments," ARBOR Ciencia, Pensamiento y Cultura, vol. 187, December 2011.

[25] E. Sancristobal, M. Castro, S. Martin, M. Tawkif, A. Pesquera, R. Gil, G. Diaz, and J. Peire, "Remote labs as learning services in the educational arena," in IEEE Global Eng. Educ. Con. (EDUCON) 2011, pp. 1189-1194.

[26] T. Richter, D. Boehringer, and S. Jeschke, "LiLa: A European Project on Networked Experiments," in REV 2009: 6th International Conference on Remote Engineering and Virtual Instrumentation, Bridgeport, USA, 2009.

[27] (2012). Lab2go. Available: http://www.lab2go.net/

[28] (2012). iLabCentral - The place to share remote online laboratories. Available: http://www.ilabcentral.org/

[29] (2012). ANECA. Available: http://www.aneca.es/

[30] (2012). Spanish University for Distance Education (UNED): Statistics. Available: http://portal.uned.es/portal/page? pageid=93,510355,93 2 0540449\&_dad=portal\&_schema=PORTAL

[31] M. Tawfik, E. Sancristobal, S. Martin, C. Gil, P. Losada, G. Diaz, and M. Castro, "Remote laboratories for electrical \&amp; electronic subjects in new engineering grades," in IEEE Fomento e Innovación con Nuevas Tecnologías en la Docencia de la Ingeniería (FINTDI), 2011, pp. 1-6.
[32] M. Tawfik, E. Sancristobal, S. Martin, C. Gil, A. Pesquera, P. Losada, G. Diaz, J. Peire, M. Castro, J. Garcia-Zubia, U. Hernandez, P. Orduna, I. Angulo, M. C. Costa Lobo, M. A. Marques, M. C. Viegas, and G. R. Alves, "VISIR deployment in undergraduate engineering practices," in Global Online Laboratory Consortium Remote Laboratories Workshop (GOLC), 2011 First, 2011, pp. 1-7. http://dx.doi.org/10.1109/GOLC. 2011.6086786

[33] M. Tawfik, E. Sancristobal, S. Martín, C. Gil, A. Pesquera, P. Losada, G. Díaz, J. Peire, M. Castro, J. García-Zubia, U. Hernández, P. Orduña, I. Angulo, M. C. C. Lobo, M. A. Marques, M. C. Viegas, and G. R. Alves, "VISIR: Experiences and Challenges," Int. J. of Online Eng. (iJOE), vol. 8, pp. 25-32, February 20122012.

[34] K. Langendoen, A. Baggio, and O. Visser, "Murphy loves potatoes: experiences from a pilot sensor network deployment in precision agriculture," in Proceedings of the 20th international conference on Parallel and distributed processing, Rhodes Island, Greece, 2006, pp. 174-174.

[35] A. Lindgren, C. Mascolo, M. Lonergan, and B. McConnell, "Seal2-Seal: A delay-tolerant protocol for contact logging in wildlife monitoring sensor networks," in Mobile Ad Hoc and Sensor Systems, 2008. MASS 2008. 5th IEEE International Conference on, 2008, pp. 321-327.

[36] K. Lorincz, B.-r. Chen, G. W. Challen, A. R. Chowdhury, S. Patel, P. Bonato, and M. Welsh, "Mercury: a wearable sensor network platform for high-fidelity motion analysis," in Proceedings of the 7th ACM Conference on Embedded Networked Sensor Systems, Berkeley, California, 2009, pp. 183-196. http://dx.doi.org/ 10.1145/1644038.1644057

[37] N. Xu, S. Rangwala, K. K. Chintalapudi, D. Ganesan, A. Broad, R. Govindan, and D. Estrin, "A wireless sensor network For structural monitoring," in Proceedings of the 2nd international conference on Embedded networked sensor systems, Baltimore, MD, USA, 2004, pp. 13-24. http://dx.doi.org/'10.1145/ 1031495.1031498

[38] M. Tauste, S. Martin, E. Sancristobal, M. Tawfik, J. Peire, and M. Castro, "Implementation of a remote laboratory for practices in FPGAs Programmable Logic Devices," in 1st Experiment@International Conference Remote \& Virtual Labs (exp.at'11), Lisbon, Portugal, 2011.

\section{AUTHORS}

Mohamed Tawfik, Elio Sancristobal, Sergio Martin, Rosario Gil, Alberto Pesquera, Maria Jose Albert, Gabriel Diaz, Juan Peire, and Manuel Castro are with Spanish University for Distance Education (UNED), Spain.

Mihail Milev is with Plovdiv University (PU), Plovdiv, Bulgaria.

Nevena Mileva and Gearoid OSuilleabhain are with Cork Institute of Technology (DEIS), Cork, Ireland.

Slavka Tzanova is with Technical University Sofia (TUS), Sofia, Bulgaria.

Christian Kreiner and Leander Bernd Hörmann are with Graz University of Technology (TUGraz), Graz, Austria.

This work was supported in part by the project Remote-labs Access in Internet-based Performance-centered Learning Environment for Curriculum Support (RIPLECS) (517836-LLP-1-2011-1-ES-ERASMUSESMO). It is an extended and modified version of a paper presented at the International Conference on Remote Engineering \& Virtual Instrumentation (REV2012), held at University of Deusto, Bilbao, Spain, July 4-6, 2012. Received 18 August 2012. Published as resubmitted by the authors 14 November 2012. 